\title{
System Analysis of Nuclear-Assisted Syngas Production from Coal
}

\section{$4^{\text {th }}$ International Topical Meeting on High Temperature Reactor Technology}

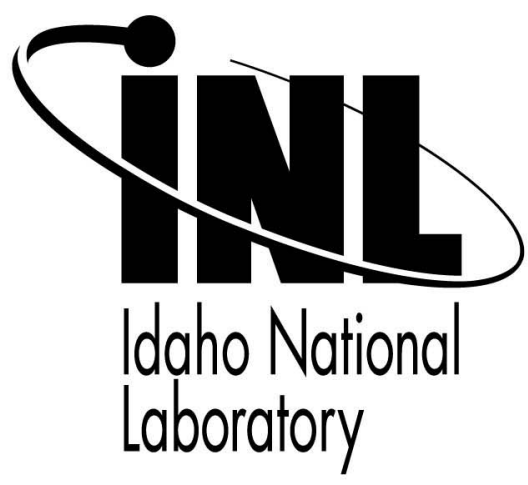

This is a preprint of a paper intended for publication in a journal or proceedings. Since changes may be made before publication, this preprint should not be cited or reproduced without permission of the author. This document was prepared as an account of work sponsored by an agency of the United States Government. Neither the United States Government nor any agency thereof, or any of their employees, makes any warranty, expressed or implied, or assumes any legal liability or responsibility for any third party's use, or the results of such use, of any information, apparatus, product or process disclosed in this report, or represents that its use by such third party would not infringe privately owned rights. The views expressed in this paper are not necessarily those of the United States Government or the sponsoring agency. 


\title{
HTR2008-58085
}

\section{SYSTEM ANALYSIS OF NUCLEAR-ASSISTED SYNGAS PRODUCTION FROM COAL}

\author{
E. A. Harvego, M. G. McKellar, and J. E. O'Brien \\ Idaho National Laboratory \\ Idaho Falls, ID, USA
}

\begin{abstract}
A system analysis has been performed to assess the efficiency and carbon utilization of a nuclear-assisted coal gasification process. The nuclear reactor is a hightemperature helium-cooled reactor that is used primarily to provide power for hydrogen production via high-temperature electrolysis. The supplemental hydrogen is mixed with the outlet stream from an oxygen-blown coal gasifier to produce a hydrogen-rich gas mixture, allowing most of the carbon dioxide to be converted into carbon monoxide, with enough excess hydrogen to produce a syngas product stream with a hydrogen/carbon monoxide molar ratio of about 2:1. Oxygen for the gasifier is also provided by the high-temperature electrolysis process. Results of the analysis predict $90.5 \%$ carbon utilization with a syngas production efficiency (defined as the ratio of the heating value of the produced syngas to the sum of the heating value of the coal plus the high-temperature reactor heat input) of $64.4 \%$ at a gasifier temperature of 1866 $\mathrm{K}$ for the high-moisture-content lignite coal considered. Usage of lower moisture coals such as bituminous can yield carbon utilization approaching $100 \%$ and $70 \%$ syngas production efficiency.
\end{abstract}

\section{INTRODUCTION}

Deepening concerns about energy security, especially with regard to liquid fuels for transportation, have motivated consideration of alternate methods for producing synthetic liquid fuels [1, 2]. Indirect coal liquefaction technology consumes coal, steam, and oxygen in a gasification process to produce hydrogen and carbon monoxide that can be converted to liquid fuels via the Fischer-Tropsch catalytic synthesis process:

$$
n \mathrm{CO}+(2 n+1) \mathrm{H}_{2} \rightarrow \mathrm{C}_{\mathrm{n}} \mathrm{H}_{2 n+2}+n \mathrm{H}_{2} \mathrm{O} .
$$

In addition to the Fischer-Tropsch process for production of liquid fuels, syngas is also the starting point for the production of many useful chemicals [3]. However, the traditional process for producing syngas also produces significant quantities of carbon dioxide that must be sequestered or released to the atmosphere. In fact, with traditional coal-to-liquids (CTL) technology, only about onethird of the carbon in the coal feedstock ends up in the liquid fuel product [4]. If supplemental hydrogen is available, nearly all of the carbon in the coal can end up in the liquid fuel product. Supplemental hydrogen for this process should be obtained from an efficient non-carbon-emitting process such as high-temperature electrolysis (HTE) of steam powered by nuclear energy $[5,6]$. Coupling of the HTE process to CTL is particularly appealing because it is more efficient than conventional electrolysis and because it provides both hydrogen and oxygen at elevated temperature. The oxygen can be fed directly to the gasifier and the hydrogen can be used to reduce the excess carbon dioxide produced in a gasifier, via the reverse shift reaction.

Nuclear-assisted CTL was analyzed in a recent study [7] for a particular advanced reactor-gasifier combination. The authors found that the most effective role for the reactor was in powering a high-temperature electrolysis process for production of hydrogen and oxygen, both of which can be used directly in the gasification and shift reactor processes. Direct integration of reactor thermal energy into the process was not found to be beneficial. Results of that study indicated that very high carbon utilization is achievable with this concept.

This paper presents results of a general system analysis that examines the details of coupling an advanced hightemperature nuclear reactor to an HTE system and a coal 
gasifier for the production of syngas. The conversion of the syngas to a liquid fuel using the Fischer-Tropsch process is not considered herein. Overall system performance is characterized over a range of gasifier temperatures and coal moisture contents. Coal consumption and syngas production rates are determined based on maximizing carbon utilization with the available hydrogen from a $600 \mathrm{MW}_{\mathrm{t}}$ advanced reactor operating at a reactor outlet temperature of $900^{\circ} \mathrm{C}$. Overall syngas production efficiency is determined as a ratio of the heating value of the produced syngas to the sum of the heating value of the coal plus the high-temperature reactor heat input.

\section{NOMENCLATURE}

$\eta_{s y n} \quad$ syngas production efficiency

$\dot{m} \quad$ mass flow rate, $\mathrm{kg} / \mathrm{s}$

MW molecular weight, $\mathrm{gm} / \mathrm{mol}$

$\dot{N} \quad$ molar flow rate, $\mathrm{mol} / \mathrm{s}$

LHV low heating value, $\mathrm{J} / \mathrm{mol}$

$\dot{Q}_{t h, \text { reactor }} \quad$ reactor thermal power, MW

$U_{C} \quad$ carbon utilization

\section{SYSTEM MODEL DESCRIPTION}

UniSim [8] process analysis software was used to evaluate the syngas production system performance. UniSim software is a derivative of the HYSYS process analysis software. Using this code, a detailed process flow sheet has been developed that includes the major components that would be present in an actual syngas production plant such as pumps, compressors, heat exchangers, turbines, etc.. These devices are included as standard UniSim components. However, since the electrolyzer is not a standard UniSim component, a custom electrolysis model was developed to handle steam electrolysis [9] for incorporation into the overall process flow sheet. UniSim inherently ensures mass and energy balances across all components and it includes thermodynamic data for all chemical species. Fig. 1 shows a process flow diagram for a nuclear-reactor-driven HTE process coupled to a syngas production plant. The process flow diagram presented in Fig. 1 is taken directly from the UniSim graphical user interface.

A Very-High-Temperature-Gas Reactor (VHTGR) with a helium recuperated Brayton power cycle operating at a $53.2 \%$ electrical conversion efficiency was selected as the power source for the combined electrolysis and syngas production plant [10]. The model for the power cycle is shown at the bottom right of Fig. 1. The primary helium coolant (stream 11) exits the reactor (VHTGR) at $900^{\circ} \mathrm{C}$, and is split at TEE100 , with approximately $95 \%$ of the flow going to the power cycle and the remainder $(\leq 5 \%)$ diverted to a process heater

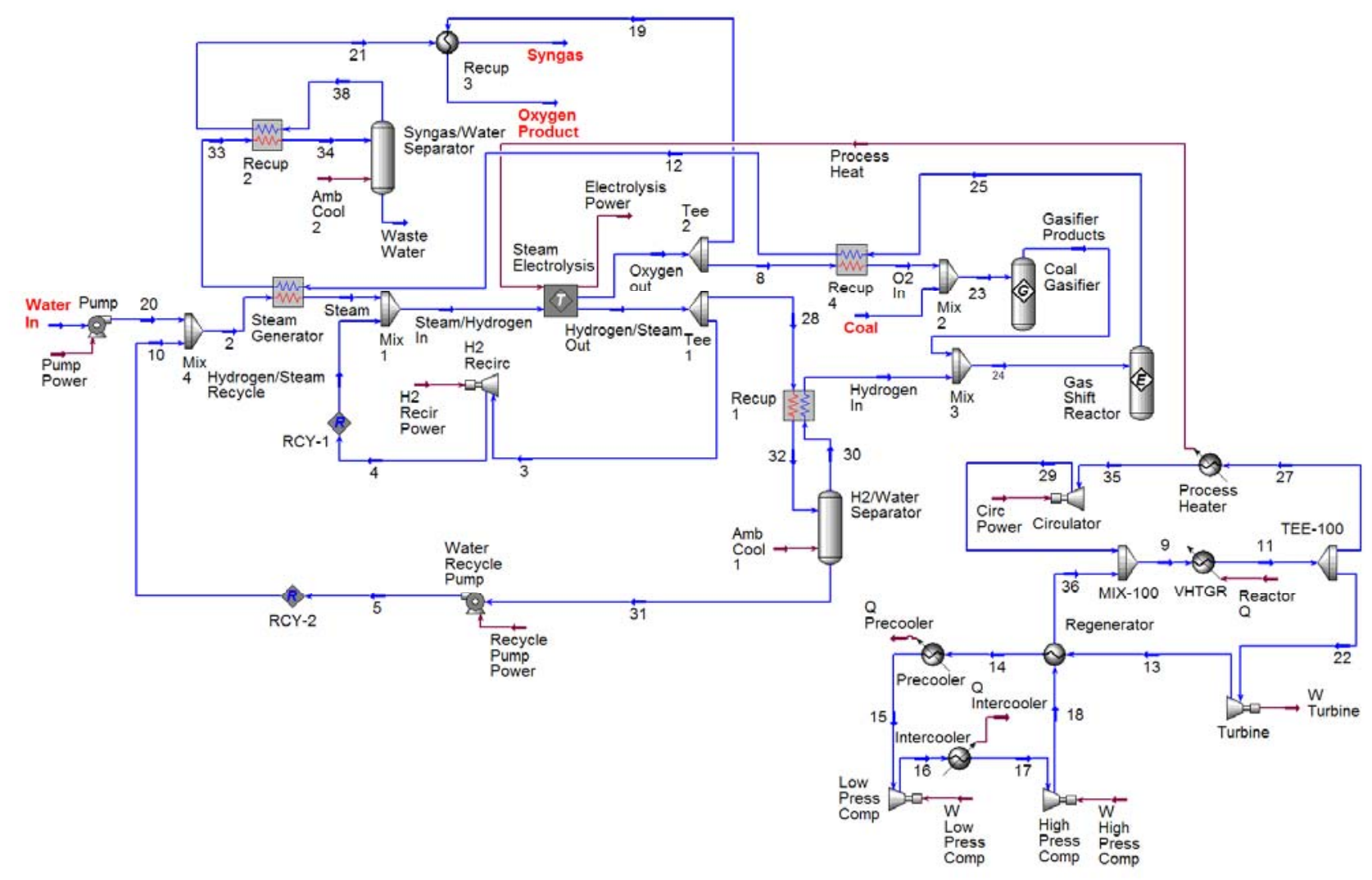

Figure 1. Process flow diagram for helium-cooled reactor/direct Brayton/HTE syngas production plant. 
that supplies heat directly to the electrolysis stack to maintain the electrolyzer operating temperature of $800^{\circ} \mathrm{C}$. The cooler helium leaving the process heater (stream 35 ) is compressed to the reactor inlet pressure and mixed with the primary coolant returning to the reactor. The helium flow from TEE-100 to the power cycle passes through a power turbine, producing electricity to drive the electrolysis process. This helium exits the power turbine at a reduced pressure and temperature, and then passes through a recuperator and precooler where it is further cooled before entering the low-pressure compressor. To improve compression efficiency, the helium is again cooled in an intercooler before entering the high-pressure compressor. The helium exits the high-pressure compressor at a pressure that is slightly higher than the reactor operating pressure of $7 \mathrm{MPa}$. The coolant then circulates back through the recuperator where the recovered heat raises its temperature to the reactor inlet temperature of $540^{\circ} \mathrm{C}$, completing the power cycle.

The water that feeds the electrolysis process enters at the left of Fig. 1 at a temperature of $15.6^{\circ} \mathrm{C}$ and is pressurized to the process pressure of approximately $2.9 \mathrm{MPa}$. Downstream of the pump, the feed water flow is combined with recycled condensate from the H2/Water Separator tank (Mix 4) and vaporized in a steam generator. At Mix 1, recycled hydrogen and steam from the electrolyzer outlet is added to the electrolysis feed stream to maintain reducing conditions at the steam-hydrogen electrode. The inlet steam-hydrogen mixture (90-10\% by volume) then enters the solid oxide electrolysis cell (SOEC) stack, where the steam is electrolytically reduced, yielding hydrogen and oxygen.

The electrolyzer model used in UniSim was developed by the INL specifically for the analysis of HTE hydrogen production processes and related concepts being developed and evaluated at the laboratory [9]. The model calculates the electrolyzer heat requirements, hydrogen and oxygen production rates, and associated product stream conditions. An embedded spreadsheet is used to calculate the Nernst potential, operating voltage, current and electrolysis power based on an integral electrolyzer model.

Downstream of the electrolyzer, a portion of the oxygen product (stream 8) passes through a recuperative heat exchanger and is mixed with the coal feedstock entering the gasifier where the coal is gasified to produce a mixture of hydrogen, carbon monoxide, carbon dioxide, steam and trace amounts of other gas contaminates. The remaining oxygen (approximately 38\%) passes through a recuperator (Recup 3) where a portion of its heat is utilized to heat the syngas product stream. This excess oxygen product stream is a valuable commodity that can either be sold or used for other process applications.

The hydrogen and steam mixture leaving the electrolyzer is split at Tee 1 with a little over $11 \%$ of the total flow recycled back to the electrolyzer inlet to maintain reducing conditions at the steam electrode as described earlier. The remaining flow (approximately 89\%) passes through a recuperator (Recup 1) where the hydrogen and steam mixture is cooled prior to entering the hydrogen/water separator (stream 32). Condensate from the hydrogen/water separator is recycled (Water Recycle Pump) back to the process inlet where it is combined with the feed water flow (Mix 1) as described earlier. Dry hydrogen from the hydrogen/water separator (stream 30) then passes back through the recuperative heat exchanger (Recup 1) where a portion of the heat lost in the condensation process is recovered. This hydrogen stream is then mixed with the product gas from the coal gasifier (Mix 3) to produce a hydrogen-rich gas mixture (stream 24). This hydrogen-enriched gas mixture then passes through the reverse shift reaction where the majority of excess carbon dioxide is converted to carbon monoxide and steam, with plenty of hydrogen remaining. The resulting syngas stream exiting the Gas Shift Reactor (Stream 25) has a hydrogen-to-carbon monoxide molar ratio of about $2: 1$, with less than $10 \%$ of the total carbon (on a mass basis) in the form of carbon dioxide. The hydrogen-rich syngas mixture then passes through a recuperator (recup 4) where a portion of its heat is transferred to the oxygen feeding the coal gasifier. The syngas then passes through the steam generator where it is further cooled by transferring its heat to the electrolyzer feed water as described earlier. After leaving the steam generator, the syngas/steam mixture (stream 33) passes through another recuperative heat exchanger where it is cooled prior to entering the Syngas/Water Separator, where most of the water is condensed to achieve the desired low moisture content for the final syngas product stream. After exiting the Syngas/Water Separator tank, the syngas again passes through the syngas recuperative heat exchangers (Recup 2 and 3) where the syngas is heated to the desired temperature of approximately $450^{\circ} \mathrm{F}\left(232^{\circ} \mathrm{C}\right)$ for the production of liquid fuel using the Fisher-Tropsch synthesis process.

\section{PARAMETRIC STUDIES}

Parametric studies were performed to investigate the impact of gasifier temperature and coal moisture content on carbon utilization and syngas production efficiency. These two studies and their results are discussed separately below.

\section{Gasifier Temperature}

A parametric study was performed in which the gasification temperature was varied from $1477 \mathrm{~K}$ to $1866 \mathrm{~K}$. For this temperature range, chemical equilibrium was assumed during the gasification process and the gasifier is modeled as a Gibbs reactor. A number of potential products were considered for the gasifier including nitrates, sulfates, and natural gas components, but the primary products were water, hydrogen, oxygen, carbon monoxide and carbon dioxide with trace amounts of nitrogen, hydrogen sulfide and ammonia.

For the parametric study, the following constraints were applied:

- All heat exchangers have a minimum approach of $20^{\circ} \mathrm{C}$ except Recup 4 which was set to $50^{\circ} \mathrm{C}$ by 
adjusting the temperature of the oxygen into the Coal Gasifier.

- The adiabatic efficiency for the power cycle turbine is $93 \%$, the power cycle compressors have efficiencies of $88 \%$, all other compressors and pumps have efficiencies of $75 \%$.

- The mass flow of the coal was adjusted until the molar ratio of hydrogen to carbon monoxide in the syngas product was 2.0 .

- The steam electrolysis process is isothermal with an operating temperature of $800^{\circ} \mathrm{C}$, cell area specific resistance of $0.4 \mathrm{Ohm} \cdot \mathrm{cm}^{2}$, a current density of 0.24 , and a cell area of $225 \mathrm{~cm}^{2}$.

- All of the $600 \mathrm{MWt}$ heat from the reactor is dedicated for syngas production, with an associated requirement of 110,000 electrolysis cells.

- The stream entering the electrolysis process is $90 \%$ steam and $10 \%$ hydrogen by mole fraction.

- The streams exiting the process are $10 \%$ steam and $90 \%$ hydrogen on the cathode side and $100 \%$ oxygen on the anode side.

To optimize the process, two figures of merit were considered: syngas production efficiency and carbon utilization. The syngas production efficiency is defined as the ratio of the heating value of the syngas produced by the process to the sum of the heat addition to the process (total thermal power rating of the reactor for a fully dedicated plant) plus the heating value of the coal that is consumed in the process:

$$
\eta_{\text {syn }}=\frac{\dot{N}_{\mathrm{H}_{2}} L H V_{\mathrm{H}_{2}}+\dot{N}_{C O} L H V_{C O}}{\dot{Q}_{\text {th,reactor }}+\dot{N}_{\text {coal }} L H V_{\text {coal }}}
$$

For this analysis the lower heating value, $L H V$, of the coal and the syngas are used to calculate the thermal power of each.

The second figure of merit for the process is the carbon utilization, defined as the mass percentage of carbon from the coal that is ultimately transferred to the carbon monoxide in the syngas. The mass flow rate of the carbon in the coal is found as the product of the mass flow rate of the dry ash-free coal, the number of carbon moles per mole of dry ash-free coal, and the molecular weight of carbon divided by the molecular weight of the dry-ash free coal.

$$
\dot{m}_{C, \text { coal }}=\dot{m}_{\text {coal-dry,af }} n_{C \rightarrow \text { coal }-d r y, a f}\left(\frac{M W_{C}}{M W_{c o a l-d r y, a f}}\right)
$$

Similarly, the carbon flow in the sygnas is found as the product of the mass flow of the carbon monoxide in the syngas, the number of moles of carbon per mole of carbon monoxide and the molecular weight of carbon divided by the molecular weight of carbon monoxide.

$$
\dot{m}_{C, \text { syngas }}=\dot{m}_{C O, \text { syngas }} n_{C \rightarrow C O}\left(\frac{M W_{C}}{M W_{C O}}\right)
$$

Finally, the carbon utilization is found by dividing equation (4) with equation (3):

$$
\begin{aligned}
U_{C}= & \frac{\dot{m}_{C, \text { syngas }}}{\dot{m}_{C, \text { coal }}}= \\
& \left(\frac{\dot{m}_{C O, \text { syngas }}}{\dot{m}_{\text {coal }- \text { dry }, \text { af }}}\right)\left(\frac{M W_{\text {coal }- \text { dry }, a f}}{M W_{C O}}\right)\left(\frac{n_{C \rightarrow C O}}{n_{C \rightarrow \text { coal }-d r y, a f}}\right)
\end{aligned}
$$

For this analysis the number of moles of carbon per mole of dry ash-free coal and the number of moles of carbon per mole of carbon dioxide are both equal to 1.0 and equation (5) reduces to

$$
U_{C}=\left(\frac{\dot{m}_{C O, \text { syngas }}}{\dot{m}_{\text {coal-dry,af }}}\right)\left(\frac{M W_{c o a l-d r y, a f}}{M W_{C O}}\right)
$$

The coal type assumed for this analysis is lignite. The lignite and ash are modeled as hypothetical components in UniSim. The lignite UniSim component has a specified atomic breakdown of the carbon, hydrogen, oxygen, nitrogen and sulfur. The heat of combustion for the lignite is also known. This information is sufficient to break down the lignite in the gasifier to produce the expected products. The ash is modeled as silica with a known heat capacity. It is used to capture heat in the gasifier that would otherwise be used for gasification of the lignite. The ash remains in the gasifier.

\section{Gasifier Temperature Sensitivity Results}

Results of the gasifier temperature parametric study are presented in Fig. 2 which shows the syngas production efficiency and carbon utilization as a function of gasification temperature. As the gasification temperature increases, the syngas production efficiency decreases slightly from $68.0 \%$ to $64.4 \%$. The decrease in efficiency is primarily due to increased heat losses in the system. The exit temperature of the syngas increases from $460 \mathrm{~K}$ to $578 \mathrm{~K}$. The ambient cooling load at the Syngas/Water Separator increases from 20 MW to $30 \mathrm{MW}$ as the temperature increases.

Carbon utilization increases slightly from $88.6 \%$ to $90.5 \%$ as the temperature increases. At higher gasification temperatures, more carbon dioxide breaks down to carbon monoxide. Also, the syngas has a higher percentage of hydrogen at higher gasification temperatures. The mole fraction of hydrogen increases from 0.635 to 0.640 . The mole fraction of carbon monoxide increases from .318 to .320 and carbon dioxide decreases from .040 to .034 .

Although contaminants like hydrogen sulfide and ammonia are formed, in this analysis contaminant removal is not considered. The process was designed to prevent contaminants from entering the electrolysis process. 


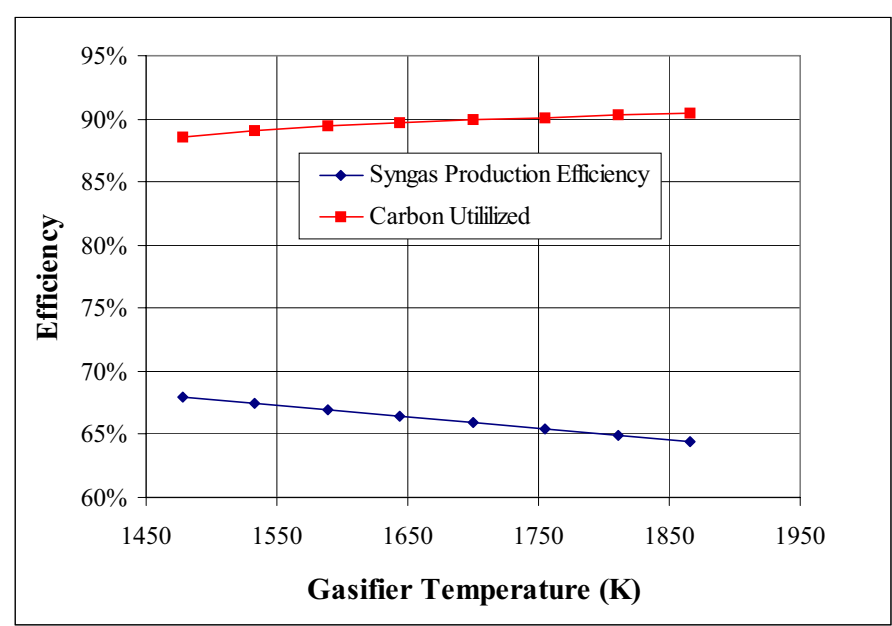

Figure 2. Syngas production efficiency and carbon utilization as a function of gasification temperature.

The current analysis assumed a lignite coal feedstock with relatively high moisture content (approximately $36.2 \%$ by mass). This relatively high moisture content, compared to other U.S. coals makes it more difficult to fully utilize the carbon content of the coal. In the current analyses, the coal was gasified without attempting to remove any of the moisture from the coal or product gas from the gasifier. Dry hydrogen was then mixed with the product gas from the coal gasifier, and fed to the reverse gas shift reactor. This process resulted in $90.5 \%$ carbon utilization with a syngas production efficiency of $64.4 \%$ at a gasifier temperature of $1866 \mathrm{~K}$. At this syngas production efficiency, approximately $55 \%$ of the energy input to the process (denominator of Equation 2) is provided by the nuclear reactor, and the remaining $45 \%$ is the heating value of the coal consumed in the process. In terms of carbon utilization, these results are extremely good compared to conventional processes, where only about $30 \%$ of the carbon in the coal ends up in the product syngas (i.e., close to $70 \%$ is converted to carbon dioxide that must be either sequestered or released to the environment). However, significantly higher carbon utilization ( $\sim 97 \%$ or greater) can be achieved by reducing the moisture content of the feed to the reverse gas shift reactor. With less moisture $\left(\mathrm{H}_{2} \mathrm{O}\right)$ in the feed stream, more carbon dioxide and hydrogen combine to produce equilibrium carbon monoxide and $\mathrm{H}_{2} \mathrm{O}$ in the syngas exiting the Reverse Shift Gas Reactor. To achieve higher carbon utilization and syngas efficiencies, with high moisture content coals, the coal would either have to be dried before gasification, or another step added to the syngas production process to remove the water from the gasifier product stream.

\section{Coal Moisture Content}

To evaluate the influence of coal moisture content on carbon utilization and syngas production efficiency, the UniSim process flow model in Fig. 1 and the process constraints identified previously were again used, but in this case, the moisture content of the coal fed to the gasifier was varied between $16.1 \%$ and $36.2 \%$. For coal moisture contents of $16.1 \%, 30.4 \%$, and $36.2 \%$, actual coal analyses from Probstein [11], corresponding to bituminous, sub bituminous, and lignite coals from various regions within the United States were used. To fill the gap in moisture content between $16.1 \%$ and $30.4 \%$, the moisture content of the sub bituminous coal was reduced from $30.4 \%$ to values of $25 \%$ and $20 \%$ to allow evaluation of the impact of moisture content in this intermediate range.

In each of the calculations, the reactor power was again fixed at $600 \mathrm{MW}_{\mathrm{t}}$ with a reactor outlet temperature of $900^{\circ} \mathrm{C}$. All of the hydrogen produced in the electrolysis process was again used in the reverse shift reaction to convert carbon dioxide to carbon monoxide, and any oxygen not used by the gasifier is assumed to be used to heat the syngas product stream and then stored for sale as a valuable commodity. The initial gasifier temperature was fixed at $1700 \mathrm{~K}\left(1427^{\circ} \mathrm{C}\right)$, but as discussed below, was gradually increased as the moisture content of the coal decreased to allow reasonable operating conditions for the heat exchangers used in the process. In all the analyses a hydrogen-to-carbon monoxide molar ratio of 2:1 was maintained for the syngas.

\section{Coal Moisture Content Sensitivity Results}

Fig. 3 shows the influence of the coal moisture content on carbon utilization and syngas production efficiency. As seen in Fig. 3, carbon utilization increases with decreased moisture content, reaching a value of $98.8 \%$ for a moisture content of $16.1 \%$. The syngas production efficiency shown in Fig. 3 also appears to increase as the moisture content is reduced, but peaks at about $68.8 \%$ for a coal moisture content of $25 \%$. The drop in syngas production efficiency as the coal moisture content is reduced below $25 \%$ is the result of the need to increase the gasifier temperature to maintain a minimum heat exchanger approach temperature for the steam generator of approximately $20^{\circ} \mathrm{C}$. This drop in syngas production efficiency is consistent with the early results in Fig. 2, which also show a drop in syngas production efficiency as the gasifier temperature increased.

Fig. 4 shows the calculated gasifier and syngas outlet temperature as a function of coal moisture content. As seen in the figure, the gasifier temperature can be maintained at 1700 $\mathrm{K}$ at moisture contents above $25 \%$, but must be increased as the moisture content drops below $25 \%$ to maintain a minimum approach temperature of $20^{\circ} \mathrm{C}$ for the steam generator. Fig. 4 also shows that the syngas outlet temperature drops from 510 $\mathrm{K}$ at a coal moisture content of $36.2 \%$ to $392 \mathrm{~K}$ at a coal moisture content of $16.1 \%$. This calculated temperature decrease was necessary to maintain a minimum approach temperature of $20^{\circ} \mathrm{C}$ at the recup 4 heat exchanger shown in Fig. 1. Nevertheless, this temperature range for the syngas product stream is still within the acceptable temperature range of the Fischer-Tropsch synthesis process.

Finally, Fig. 5 shows the mass flow rates for coal and syngas as a function of coal moisture content. For a fixed 


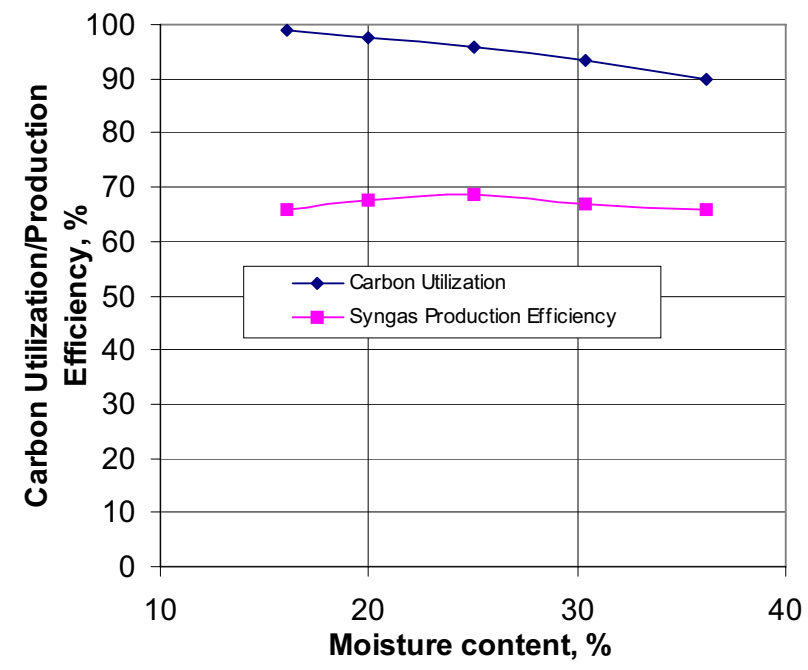

Figure 3. Carbon utilization and syngas production efficiency as a function of coal moisture content.

reactor power and a fixed number of electrolysis cells the overall syngas production rate increases with increased coal moisture content, but at the expense of a reduction in carbon utilization and syngas production efficiency (as shown previously in Fig. 3). The reduction in syngas production efficiency is also apparent in Fig. 5, which shows that the mass flow of syngas being produced increases at a slower rate than the mass flow of coal being consumed as the moisture content of the coal increases.

\section{CONCLUSIONS}

Production of syngas from coal with supplemental hydrogen and oxygen from nuclear reactor has been analyzed. The nuclear reactor under consideration is a high-temperature helium-cooled reactor that is used primarily to provide power

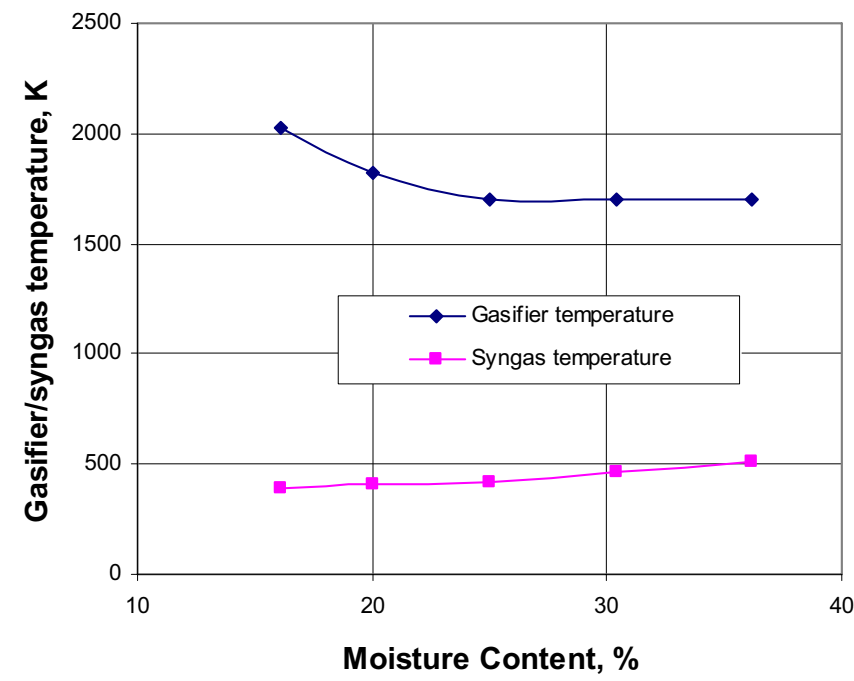

Figure 4. Gasifier and syngas temperatures as a function of coal moisture content.

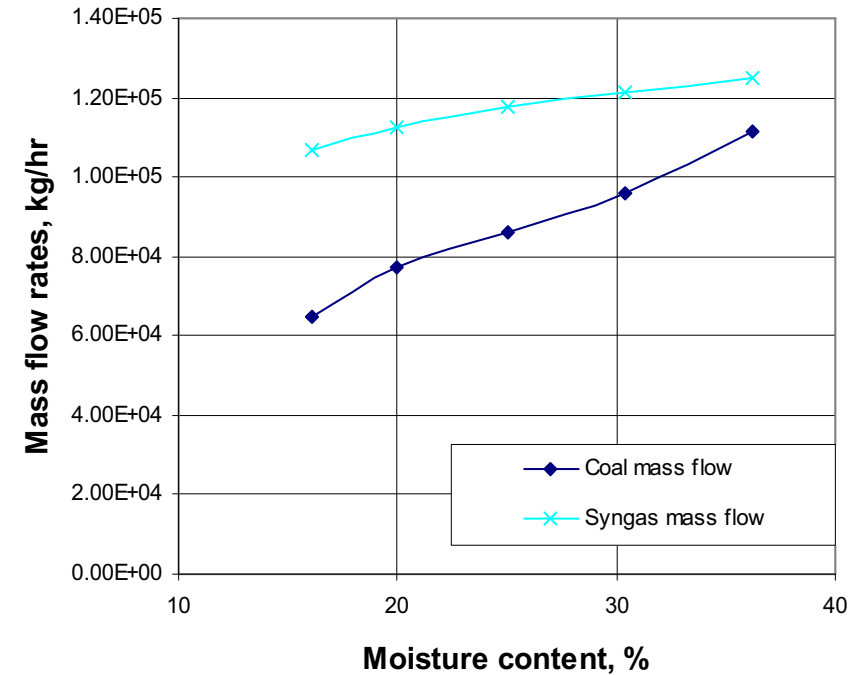

Figure 5. Coal and syngas mass flow rates as a function of coal moisture content.

for hydrogen production via high-temperature electrolysis. The supplemental hydrogen enables conversion of most of the carbon dioxide to carbon monoxide, with enough excess hydrogen to produce a syngas product stream with a hydrogen/carbon monoxide molar ratio of about $2: 1$, ideal for subsequent conversion to liquid fuel via a Fischer-Tropsch process with a cobalt catalyst. Oxygen for the gasifier is also provided by the high-temperature electrolysis process. Results of the analysis predict $90.5 \%$ carbon utilization with a syngas production efficiency of $64.4 \%$ at a gasifier temperature of $1866 \mathrm{~K}$ for the high-moisture-content lignite coal considered.

Parametric studies show that carbon utilization increases with increased gasifier temperature, while syngas production efficiency decreases slightly with increased gasifier temperature. Carbon utilization was also found to increase with lower moisture coals. A maximum carbon utilization value of $98.8 \%$ was obtained for the low moisture content bituminous coal ( $16.1 \%$ moisture) at a gasifier temperature of $2030 \mathrm{~K}$ and a syngas production efficiency of $65.7 \%$.

\section{ACKNOWLEDGMENTS}

This work was supported by the Idaho National Laboratory, Laboratory Directed Research and Development program and by the U.S. Department of Energy, Office of Nuclear Energy, Nuclear Hydrogen Initiative Program.

\section{COPYRIGHT STATEMENT}

This manuscript has been authored by Battelle Energy Alliance, LLC under Contract No. DE-AC07-05ID14517 with the U.S. Department of Energy. The United States Government retains and the publisher, by accepting the article for publication, acknowledges that the United States Government retains a nonexclusive, paid-up, irrevocable, world-wide license to publish or reproduce the published form 
of this manuscript, or allow others to do so, for United States Government purposes.

\section{REFERENCES}

1. Forsberg, C. W., "Nuclear Hydrogen for Production of Liquid Hydrocarbon Transport Fuels," Proceedings, AIChE Annual Mtg., pp. 7988-7995, 2005.

2. Schultz, K., Bogart, S. L., and Noceti, R. P., "Synthesis of hydrocarbon fuels using renewable and nuclear energy," Proceedings, International Topical Meeting on the Safety and Technology of Nuclear Hydrogen Production, Control, and Management, ANS Embedded Topical, 2007.

3. Smith, R. G., "Eastman Chemical Company Kingsport Plan Chemicals from Coal Operations 1983-2000", 2000 Gasification Technologies Conference, Oct. 8-11,2000, San Francisco, CA.

4. Forsberg, C. W., "Is Hydrogen the Future of Nuclear Energy?" Proceedings, International Topical Meeting on the Safety and Technology of Nuclear Hydrogen Production, Control, and Management, ANS Embedded Topical, 2007.

5. O’Brien, J. E., Stoots, C. M., Herring, J. S., Lessing, P. A., Hartvigsen, J. J., and Elangovan, S., "Performance Measurements of Solid-Oxide Electrolysis Cells for Hydrogen Production from Nuclear Energy," Journal of Fuel Cell Science and Technology, Vol. 2, pp. 156-163, August 2005.

6. O'Brien, J. E., Stoots, C. M., Herring, J. S., and Hartvigsen, J. J., "Hydrogen Production Performance of a 10-Cell Planar Solid-Oxide Electrolysis Stack," Journal of Fuel Cell Science and Technology, 3, pp. 213-219, (2006).

7. Cherry, R. S., and Wood, R. A., "Use of a Nuclear HighTemperature Gas Reactor in a Coal-to-Liquids Process," INL External Report, INL/EXT-06-11667, Aug. 2006.

8. UniSim Design, R360 Build 12073, Copyright (C20052006 Honeywell International Inc.

9. O'Brien, J. E., Stoots, C. M., and Hawkes, G. L., "Comparison of a One-Dimensional Model of a HighTemperature Solid-Oxide Electrolysis Stack with CFD and Experimental Results," 2005 ASME International Mechanical Engineering Congress and Exposition, Nov. 5 -11 , Orlando, FL.

10. O'Brien, J. E., McKellar, M. G., and Herring, J. S., "Commercial-Scale Performance Predictions for HighTemperature Electrolysis Plants Coupled to Three Advanced Reactor Types," Proceeding of the 2008 International Congress on Advances in Nuclear Power Plants, ICAPP08, Anaheim, CA, June, 2008.

11. Probstein, R. F., and Hicks, R. E., "Synthetic Fuels", Copyright (C2006, Dover Publications, Inc., Mineola, NY. 